CUADERNOS DE ESTUDIOS GALLEGOS, LXI Núm. 127 (enero-diciembre 2014), págs. 219-250

ISSN: $0210-847 \mathrm{X}$

DOI: 10.3989/ceg.2014.127.07

\title{
APUNTES SOBRE LA GEOGRAFÍA ECLESIÁSTICA DE OURENSE: TOURÉM, LAMA DE ARCOS, «COUTO MIXTO»Y «PUEBLOS PROMISCUOS»
}

José RAMÓN HeRnández Figueiredo

Instituto Teológico del "Divino Maestro" de Ourense 


\title{
APUNTES SOBRE LA GEOGRAFÍA ECLESIÁSTICA DE OURENSE: TOURÉM, LAMA DE ARCOS, «COUTO MIXTO»Y «PUEBLOS PROMISCUOS»
}

\section{RESUMEN}

Conocer la geografía eclesiástica de una diócesis resulta ser una tarea fundamental para comprender su memoria histórica. Los inéditos fondos vaticanos ofrecen una valiosa información para conocer las luces y las sombras de la Iglesia diocesana en el periodo contemporáneo. En este artículo se presentan los procesos documentales del desmembramiento de las parroquias de San Pedro de Tourém y Santa María de Lama de Arcos, así como la solución a la cuestión del "Couto Mixto" y los "Pueblos Promisicuos", y el último arreglo del decreto de la Congregación Consistorial de 1954.

PAlabras Clave: Ourense, geografía eclesiástica, reforma, clero, parroquias, Ciudad del Vaticano.

\section{APUNTES SOBRE A XEOGRAFÍA ECLESIÁSTICA DE OURENSE: TOURÉM, LAMA DE ARCOS, «COUTO MIXTO»E «POBOS PROMISCUOS»}

\section{RESUMo}

Coñecer a xeografía eclesiástica dunha diocese resulta ser unha tarefa fundamental para comprender a súa memoria histórica. Os inéditos fondos vaticanos ofrecen unha valiosa información para coñecer as luces e as sombras da Igrexa diocesana no periodo contemporáneo. Neste artigo preséntanse os procesos documentais do desmembramento das parroquias de San Pedro de Tourém e Santa María de Lama de Arcos, así como a solución á cuestión do "Couto Mixto" e os "Pobos Promisicuos", e o último arranxo do decreto da Congregación Consistorial de 1954.

Palabras Clave: Ourense, xeografía eclesiástica, reforma, clero, parroquias, Cidade do Vaticano.

\section{NOTES ON THE ECCLESIASTICAL GEOGRAPHY OF OURENSE: TOURÉM, LAMA OF ARCOS, «COUTO MIXTO»AND «PROMISCUOUS TOWNS»}

\begin{abstract}
Meet the ecclesiastical geography of a diocese is to be a key task to understand their historical memory. The previously unknown files of the Vatican offer valuable information for knowing the lights and shadows of the Diocesan Church in the contemporary period. Presented in this article document processes of the dismemberment of the parish church of St. Peter of Tourém and St. Mary of Lama de Arcos, and the solution to the question of the "Couto Mixto" and "Pueblos Promiscuos", and the last under the decree of the Congregation Consistorial of 1954.

KEY WORDS: Ourense, Ecclesiastical Geography, Reform, Clergy, Parish church, Vatican City.
\end{abstract}


Recibido/Received: 21/01/2014

Aceptado/Accepted: 02/09/2014

\section{INTRODUCCIÓN}

$\mathrm{D}$ os son las coordenadas básicas que ayudan a situar cualquier acontecimiento que merezca la pena pasar a la memoria histórica de un colectivo: el tiempo (kronos) y el lugar (topos). Por eso, tarea primera del historiador de la Iglesia ha de ser el estudio de todos los elementos que constituyen y explican la evolución y la configuración de la geografía eclesiástica. Así se hará en el presente estudio en cuanto a la geografía diocesana auriense en su etapa más contemporánea.

Sobre este aspecto, existe una importante contribución referida a todas las diócesis de España en la obra de monseñor Mansilla Reoyo, que aborda el argumento de la constitución de las mismas en las épocas antigua, medieval y moderna ${ }^{1}$. Sufragánea de Braga hasta 1394 y dependiente, en lo político, de Compostela, Ourense acusa el influjo de ambas en lo que a su distribución se refiere. A imitación de aquellas, la organización catedralicia contemplaba a las dignidades con sus respectivos distritos.

A nivel diocesano, es de máximo interés el artículo de Duro Peña sobre las antiguas dignidades de la catedral que, en la Baja Edad Media, ocupaban un lugar preponderante no solo en el mismo cabildo, sino en toda la diócesis por su personalidad y jurisdicción. Nacen en el siglo XII, "uno de los más interesantes de nuestra historia diocesana", que está marcado por un empuje dinámico y una floración de vida eclesiástica sin igual: comienza a levantarse la catedral, es

\footnotetext{
1 * Siglas: AHDOu = Archivo Histórico Diocesano de Ourense; Arch. Nunz. = Archivio di Nunciatura; ASV = Archivio Segreto Vaticano; Congr. Consist. $=$ Sacra Congregatio Consistorialis; Segr. Stato $=$ Segreteria di Stato .

Abreviaturas: cfr. $=$ confróntese; dir., dirs. = director, $-\mathrm{a} /$ directores, -as; ed., eds. = editor, $-\mathrm{a} /$ editores, -as; fasc., fascs. = fascículo(s); fol., fols. = folio(s); ibíd.= ibídem; íd.= ídem; leg. = legajo; núm., núms. = número(s); pág., págs.. = página(s); vol., vols. = volumen, volúmenes .

Demetrio Mansilla Reoyo, Geografía eclesiástica de España. Estudio histórico-geográfico de las diócesis, 2 vols., Roma, Iglesia Nacional Española, 1994.
} 
edificada la mayoría de las iglesias románicas rurales y se organiza el cabildo auriense en dignidades ${ }^{2}$.

Por orden de antigüedad y precedencia, son doce: deán, chantre, arcediano de Castela, arcediano de Limia, arcediano de Varoncelle, arcediano de Búbal, maestrescuela, tesorero, arcediano de Celanova, abad de la Santísima Trinidad, arcediano de Ourense y vicariato. Hasta el Concilio de Trento no se puede hacer una historia de la diócesis y del medioevo sin contar con ellas. Desde Trento hasta el concordato de 1851, el obispado continuó dividido según las dignidades a ellas encomendadas. A su vez, la amplitud de las mismas exigía una serie de subdivisiones pastorales, los arciprestazgos.

En 1851, había veinte arciprestazgos, según el decreto firmado por el vicario capitular, el Dr. D. Manuel Nobo; en 1893, treinta arciprestazgos, según consta en el decreto episcopal del obispo Cesáreo Rodrigo Rodríguez (1876-1895); en 1908, treinta y siete arciprestazgos, tal como se observa en las constituciones sinodales del obispo Eustaquio Ilundain (1904-1921) ${ }^{4}$; en 1955, cuarenta y cinco arciprestazgos, por decreto del obispo Ángel Temiño Sáiz (1953-1987)5 en 1989, veintiocho arciprestazgos, tal como decreta el obispo José Diéguez Reboredo (1987-1996) ${ }^{6}$; en 2013, doce arciprestazgos, nuevo orden geográfico que aprueba el obispo actual José Leonardo Lemos Montanet ${ }^{7}$.

\section{OBJETO DE ESTUdio}

La historia de la Iglesia de As Burgas es muy deficitaria de estudios que ayuden a comprender la fisonomía actual de los límites de la diócesis auriense, al

2 Es aleccionador el estudio del gran investigador y anterior archivero catedralicio Emilio Duro Peña, "Las antiguas dignidades de la Catedral de Orense", Anuario de Estudios Medievales, 1 (1964), págs. 289-332.

3 "Arreglo parroquial de la Diócesis de Orense", Boletín Oficial del Obispado de Orense, XLIII, núm. 1379 (7 diciembre 1893), págs. 1-98. Se trata de un número extraordinario del Boletín, que resulta de máximo interés por detallar los pueblos que conforman cada una de las parroquias de la diócesis auriense.

${ }^{4}$ Se publicaron en un tomo: Eustaquio Ilundain y Esteban, Constituciones Sinodales promulgadas por el Excmo. e Ilmo. Señor Dr. D. Eustaquio Ilundain y Esteban, obispo de Orense, senador del Reino, etc. etc. En el Sínodo Diocesano celebrado en la Santa Iglesia Catedral de Orense los días 14, 15 y 16 de junio de 1908, Orense, Imprenta de A. Otero, 1908, págs. 121-125.

5 "Decreto de la nueva división de la Diócesis en Arciprestazgos", Boletín Oficial del Obispado de Orense, CXXII, núm. 11 (1 noviembre 1955), págs. 559-582.

6 "Nueva configuración de los arciprestazgos", Boletín Oficial del Obispado de Orense, CLII, núms. 5-6 (mayo-junio 1989), págs. 158-169.

7 J. Leonardo Lemos Montanet, Carta pastoral Los arciprestazgos: una estructura viva para una tarea de futuro, Ourense, 2013, 21 págs.; "La restructuración arciprestal de la Diócesis de Ourense (Año 2013)”, Pastoralia, 43 (noviembre 2013), 48 págs. 
menos en su etapa más contemporánea. Por lo que respecta a la contemporaneidad de nuestra historia diocesana, nos encontramos con un importante vacío que apenas llena la introducción general de alguna guía eclesiástica ${ }^{8}$ o la concisa apreciación de algún que otro estudio particular ${ }^{9}$.

La provincia de Ourense tiene apariencia de una enorme mano, cuya palma está cruzada por infinidad de rayas o pliegues, a través de los cuales se puede leer el pasado, el presente y parte del futuro. La rugosa superficie orensana se muestra dibujada por la hendidura de numerosos ríos que le dan una configuración propia, siendo en el Sur donde se establece la "gran raya" que Miño, Limia, Salas y Támega trazan de un modo peculiar al crear la división natural que da pie a la línea fronteriza entre España y Portugal.

En este sentido, pretendo con el presente artículo paliar las lagunas historiográficas sobre la evolución de los lindes territoriales diocesanos en general y, sobre todo, en su relación con las diócesis del país vecino, Portugal. Por consiguiente, no me refiero tanto a la frontera pública, civil o estatal, la cual ha sido suficientemente abordada en diversas monografías, entre las que sobresale la del historiador Luis Manuel García Mañá ${ }^{10}$.

A la clarificación del actual mapa geográfico de la diócesis auriense en su delimitación fronteriza con Portugal quisiera seguir contribuyendo con estas breves notas. Por una parte, se recoge la información existente sobre la incorporación de dos parroquias orensanas al arzobispado de Braga el 4 de septiembre de 1882, acontecimiento que llama la atención por su carácter internacional, lo que genera cierta documentación inédita que solo me ha sido posible hallar y consultar gracias a la búsqueda en los fondos de Nunziatura di Madrid, en el Archivio Segreto Vaticano ${ }^{11}$.

Por otra parte, los últimos esfuerzos realizados por conformar los lindes eclesiásticos con aquellos civiles de la diócesis de Ourense por su frontera Sur, datan del 7 de agosto de 1914, fecha del decreto de la Sagrada Congregación Consistorial, por el que se sustraen a la Iglesia particular auriense los lugares de Cambedo y Souteliño, que siendo civilmente dependientes del Reino de Portugal, se agregan a la archidiócesis de Braga. La ejecución del referido decreto corre a cargo del nuncio apostólico de Madrid y arzobispo titular de Mira, D. Francesco

\footnotetext{
8 José Carlos Fernández Otero, Guía de la Diócesis de Ourense, Ourense, Diputación de Ourense, 1997, págs. 31-76.

9 Miguel Ángel González García, “La diócesis de Orense desde 1850”, en José García Oro (coord.), Historia de las diócesis españolas: Iglesias de Lugo, Mondoñedo-Ferrol y Orense, vol. 15, Madrid, BAC, 2002, págs. 536-538.

${ }^{10}$ Luis Manuel García Mañá, La frontera hispano-lusa en la provincia de Ourense, Ourense, Museo Arqueológico Provincial, 1988 (Anexo 11 de Boletín Auriense).

11 ASV, Arch. Nunz. Madrid, caja 535, título VI, rúbrica I, sección I, núm. 19, fols. 673r-733r.
} 
Ragonesi, el 27 de noviembre del mismo año ${ }^{12}$. Por último, se hace referencia al último arreglo de geografía diocesana en tiempos de monseñor Temiño.

\section{Las Parroquias de Tourém y Lama de Arcos}

A finales del siglo XIX, tiene lugar una seria tentativa que se traducirá en realidad al procurar hacer converger los lindes civiles con aquellos eclesiásticos, especialmente con la delimitación de las fronteras estatales entre España y Portugal. Fruto de este esfuerzo será la desmembración de dos parroquias orensanas que pasarán a formar parte de la archidiócesis bracarense ${ }^{13}$. Es digno de mención este caso por la peculiaridad del mismo, a la vez que resulta de interés por dar a conocer el modus operandi sobre el particular.

\subsection{Breve descripción de las parroquias}

En el Archivo Histórico Diocesano apenas se conservan datos sobre ambas parroquias a no ser los que se recogen en el libro de Estadística mandado elaborar por el canónigo cardenal Juan Manuel Bedoya, vicario capitular de la diócesis auriense entre 1840 y 1847 . Este había sido desterrado a cuatro leguas de la ciudad de Ourense por sus ideas liberales en la década ominosa, pero que gozaría de fama y reconocimiento en los años siguientes hasta el punto de recibir el nombramiento de obispo de esta diócesis, lo que no aceptaría a causa de su ancianidad y enfermedad ${ }^{14}$.

Es conocido este pueblecito portugués, porque sirvió de lugar de refugio para el cardenal Quevedo y Quintano, quien al negarse a jurar la constitución de Cádiz de 1812, tuvo que ser desterrado ${ }^{15}$. Allí permanece hasta el 20 de mayo de 1814, en que termina su exilio. Desde esta parroquia dirigirá su Manifiesto a la

\footnotetext{
${ }^{12}$ Boletín Oficial de la Diócesis de Orense, LXXXII, núm. 1869 (24 abril 1915), págs. 118-120.

${ }^{13}$ José Ramón Hernández Figueiredo, “Tentativa por conformar las divisiones, eclesiástica y pública, de los Reinos de España y Portugal. El caso de las parroquias de San Pedro de Tourém y Santa María de Lama de Arcos", Memoria Ecclesiae, 27 (2005), págs. 449-462. Recoge las Actas del Congreso de la Asociación de Archiveros de la Iglesia en España, celebrado en Tenerife-Las Palmas, en el año 2003, sobre Geografía eclesiástica y archivos de la Iglesia.

${ }^{14}$ Cfr. José Ramón Hernández Figueiredo, "Correspondencia vaticana inédita sobre la jurisdicción del deán Juan Manuel Bedoya, en sede vacante (1841-1847)”, Auriensia, 15 (2012), págs. 207304; íd., "Manifiesto del canónigo cardenal Juan Manuel Bedoya en defensa de la pureza doctrinal que contienen sus escritos", Auriensia, 16 (2013), págs. 147-195; íd., Actas inéditas del deán Juan Manuel Bedoya, durante su elección como gobernador eclesiástico de Ourense en sede vacante (1841-1847), Roma, Instituto Español de Historia Eclesiástica, 2013, 227 págs.

15 José Ramón Hernández Figueiredo, "El obispo Pedro de Quevedo y Quintano (1776-1818), víctima de la política liberal de las Cortes de Cádiz", Salmanticensis, 58, fasc. 2 (mayo-agosto 2011), págs. 315-348; íd., El cardenal Pedro de Quevedo y Quintano en las Cortes de Cádiz, Madrid, BAC, 2012.
} 
nación española el 21 de abril de $1813^{16}$. Seguirá sus pasos monseñor Iglesias Lago, al buscar también refugio en este lugar durante el trienio liberal.

De San Pedro de Tourém, la Estadística elaborada por el gobernador eclesiástico Bedoya informa sobre su pertenencia al partido judicial de Montealegre, que es de presentación laical y que la componen 111 vecinos (450 almas). No consta de anejos, pero sí de varias capillas, que son propiedad del pueblo, dedicadas a Nuestra Señora del Rosario, a San Miguel y a San Lorenzo ${ }^{17}$.

Además figuran los nombres de los últimos administradores parroquiales: Joao da Costa Ferreira, natural de Calendario (Braga); Joao Leda y Manoel López, de Tourém (Ourense); Policarpo Conde, de Allariz (Ourense), religioso exclaustrado de la orden de los mercedarios; el subdiácono Francisco Rodríguez y el tonsurado Joaquín Fernández, de Tourém (Ourense). "Nao ha sacristán propio, mas exerce gratuitamente este ministerio un home do povo nomeado por turno en cada ano segundo o uso, e costume antiquisimo"18.

Por lo que respecta a Santa María de Lama de Arcos, esta aparece como anejo de Santa María de Feces de Abajo en la fecha de la elaboración de la referida Estadística por el señor Bedoya ${ }^{19}$. Pertenece a la dignidad de Varoncelle, al partido judicial de Verín, es de patronato laical, de primer ascenso (dentro de la clasificación de entrada, primer ascenso y segundo ascenso o término, que no se utiliza en Portugal y por tanto no consta respecto a San Pedro de Tourém), y la componen 53 vecinos (169 almas).

\subsection{El concordato de 1851}

El 17 de octubre de 1851 adquiría categoría de ley del Reino el Concordato suscrito meses antes por la Santa Sede y el Gobierno español. No había sido obra de improvisación. Durante seis años se habían sucedido pacientes negociaciones, en diálogos fecundos y no exentos de dificultades. Desde que las Cortes autorizaron al Gobierno español a abrir las negociaciones, en mayo de 1845, hasta primero de abril de 1851, en que Isabel II estampara su firma sobre el solemne protocolo, las partes contratantes habían dado pruebas más que suficientes

\footnotetext{
${ }^{16}$ ASV, Arch. Nunz. Madrid, caja 234, Oggetti varii ecclesiastici anteriori al 1814, fasc. 2, fols. 290r-291r, que titula "Esilio del vescovo di Orense nel 1812, per non aver voluto giurare la Costituzione". Un ejemplar se halla en ASV, Arch. Nunz. Madrid, caja 260, Oggetti varii, título XII, fols. 601-646.

${ }^{17}$ Relación núm. 1 de la parroquia de San Pedro de Torey, en AHDOu, Estadística, libro 1844, leg. 6516.

${ }^{18}$ Relación núm. 2 de la parroquia de San Pedro de Torey, en ibíd., leg. 6516; Personal de la parroquia de San Pedro de Torey, en AHDOu, Estadística, libro 1845, leg. 6513.

${ }^{19}$ No hay noticia de este anejo, pero sí de la parroquia matriz en Relación núm. 1 de la parroquia de Santa María de Feces de Abajo, en AHDOu, Estadística, libro 1844, leg. 6516.
} 
de buena voluntad, única vía posible para la solución de los graves problemas pendientes en las relaciones Iglesia-Estado ${ }^{20}$.

Desde el punto de vista eclesiástico, el Concordato representaba el hecho histórico más notable de la Iglesia española durante el siglo XIX. Desde el punto de vista civil, el Concordato devolvió la tranquilidad a muchas conciencias, turbadas por la adquisición violenta e irregular de los bienes de la Iglesia. Gran parte del honor de este Concordato corresponde al inteligente, eficaz y virtuoso Bravo Murillo, alentador en todo tiempo de las negociaciones, y bajo cuyo mandato presidencial adquirió el rango de Ley del Estado español ${ }^{21}$.

Con el Concordato de 1851 comienza una nueva etapa de la historia de la Iglesia española que prácticamente se traduce en la distribución de los territorios diocesanos en arciprestazgos como una medida administrativo-pastoral que busca una mayor eficacia en la gobernabilidad de las diócesis de España, y que sustituye a la articulación medieval en arcedianatos dependientes de las diversas dignidades catedralicias. Dos artículos dedicó el Concordato a regular el nuevo arreglo y demarcación parroquial: el $24^{22}$ y el $27^{23}$. La magnitud de este Concordato supuso un cambio, una ruptura con las anteriores estructuras. La legislación

\footnotetext{
${ }^{20}$ La edición bilingüe, en Angelo Mercati (ed.), Raccolta dei Concordati su materie ecclesiastiche tra la Santa Sede e le autorità civili, vol. 1: 1098-1914, Città del Vaticano, Tipografia Poliglotta Vaticana, 1954, págs. 771-795. La negociación del concordato debe seguirse a través de la correspondencia del nuncio Brunelli, en Vicente CÁrCEL OrTí, "Los despachos de la Nunciatura de Madrid (1847-1857)", Archivum Historiae Pontificiae, 13 (1975), págs. 311-400; 14 (1976), págs. 265-356. Los dos mejores estudios son de Federico SuÁrez, "Génesis del Concordato de 1851", Ius Canonicum, 3 (1963), págs. 65-249; Juan Pérez AlHama, La Iglesia y el Estado español. Estudio histórico-jurídico a través del concordato de 1851, Madrid, Instituto de Estudios Políticos, 1967.

${ }^{21}$ Cfr. Vicente Cárcel Ortí, “El liberalismo en el poder (1833-68)”, en Ricardo García Villoslada (coord.), Historia de la Iglesia en España: La Iglesia en la España contemporánea, vol. 5, Madrid, BAC, 1979, págs. 154-158; Lamberto DE ECHEverría, "El Concordato español de 1851", en Augustin Fliche - Victor Martín (coords.), Historia de la Iglesia, vol. 24, Valencia, EDICEP, 1976, págs. 594-611.

${ }^{22}$ Artículo 24: "A fin de que en todos los pueblos del reino se atienda con el esmero debido al culto religioso y a todas las necesidades del pasto espiritual, los M. RR. Arzobispos y RR. Obispos procederán desde luego a formar un nuevo arreglo y demarcación parroquial de sus respectivas diócesis, teniendo en cuenta la extensión y naturaleza del territorio y de la población y las demás circunstancias locales, oyendo a los cabildos catedrales, a los respectivos arciprestes y a los fiscales de los tribunales eclesiásticos, y tomando por su parte todas las disposiciones necesarias a fin de que pueda darse por concluido y ponerse en ejecución el precitado arreglo, previo el acuerdo del Gobierno de S. M., en el menor término posible".

${ }^{23}$ Artículo 27: "Se dictarán las medidas convenientes para conseguir, en cuanto sea posible, que por el nuevo arreglo eclesiástico no queden lastimados los derechos de los actuales poseedores de cualesquiera prebendas, beneficios o cargos que hubieren de suprimirse a consecuencia de lo que en él se determina".
} 
del Antiguo Régimen se venía abajo y se ponían las bases para un sistema más sencillo, racional y de acuerdo con los nuevos tiempos.

Tales artículos fueron llevándose a la práctica, no sin trabajo por parte del Estado como de la Iglesia. La restructuración territorial fue obra que requirió su tiempo, habida cuenta de los intereses particulares que había por medio. En virtud de la Real Cédula de 30 de diciembre de 1851, la diócesis auriense se divide en 20 arciprestazgos, 524 parroquias y 99 anejos ${ }^{24}$. En definitiva es una estructura que servirá de base para las futuras restructuraciones, siendo de gran relieve la que corresponde al obispo Cesáreo Rodrigo ${ }^{25}$.

\subsection{Comienzo de las negociaciones}

El 3 de marzo de 1881, el secretario de Estado de los Negocios Eclesiásticos y de Justicia del vecino reino de Portugal, don Adriao d'Abren Casiodoro Machado, manifiesta al obispo de Ourense el propósito de aquel Gobierno de armonizar de acuerdo con la Santa Sede la división eclesiástica y civil de su territorio. Le suplica al obispo de Ourense que ceda las jurisdicciones que ejerce en la actualidad sobre las parroquias de San Pedro de Tourém y Santa María de Lama de Arcos. Desde muy antiguo, la primera forma parte del concejo de Montealegre, en el distrito administrativo de Villa Real, y sin embargo siempre ha pertenecido a la diócesis de As Burgas. Su Majestad Fidelísima, como Duque de Braganza, presenta para este curato, y el obispo de Ourense da la institución y colación, servantis servandis, al clérigo presentado.

La segunda es filial o anejo de la parroquia de Feces de Abajo, de la diócesis auriense. La matriz está en territorio español y el anejo en territorio portugués desde la última demarcación de límites. Es de patronato laical, del conde de Monterrey. Lo que se pide es que estas dos parroquias sean incorporadas a la diócesis primada de Braga y, por tanto, se agreguen ya definitivamente al territorio del reino de Portugal. La principal razón que parece que ha movido al Gobierno portugués a pedir a Su Santidad que San Pedro de Tourém y Santa María de Lama de Arcos se incorporen a la archidiócesis bracarense, es la conveniencia de la conformidad de la división eclesiástica con la división pública de los dos

\footnotetext{
24 "Nota de las Parroquias que comprende cada uno de los Arciprestazgos formados en esta diócesis. Orense, 3 de junio de 1852", Boletín Eclesiástico del Obispado y Provincia de Orense, II, núm. 72 ( 5 junio 1852), págs. 575-577; núm. 73 (12 junio 1852), págs. 583-585; núm. 74 (19 junio 1852), págs. 591-592; núm. 75 (26 junio 1852), págs. 599-600; núm. 76 (3 julio 1852), págs. 607609.

25 "Arreglo parroquial de la Diócesis de Ourense", Boletín Eclesiástico del Obispado de Orense, XLIII, núm. 1379 (7 diciembre 1893), págs. 1-98.
} 
Reinos, y el evitar las dificultades que se encuentran fácilmente en la administración de dichas feligresías ${ }^{26}$.

El obispo Cesáreo Rodrigo se muestra solícito a la petición del Estado portugués. En su contestación, recuerda que en la última demarcación de límites se agregó al territorio de ese Reino el área de dicho anejo de Santa María de Lama de Arcos, continuando sin variación alguna la dependencia canónica, e incluso la dotación del culto y del coadjutor que sigue pagando el Erario español. Hay, pues, en Lama de Arcos, dos feligresías de las cuales, una pertenece a la diócesis de Ourense y otra a la de Braga. Tanto al Ministro de Gracia y Justicia ${ }^{27}$, como al gobierno de Portugal, el prelado Cesáreo hará llegar su sentir:

\begin{abstract}
Muy honroso es para mí y de gran satisfacción que formen parte de mi Diócesis las expresadas feligresías de San Pedro de Tourém y Santa María de Lama de Arcos, de cuyos moradores he recibido señaladas pruebas de veneración y de amor en la santa pastoral visita. Los amo y sentiré su separación. Sin embargo cumple á mi deber manifestar á $V$. E. que estaré siempre á lo que resuelva la Santa Sede, y así lo digo también al Excmo. Sr. Ministro de Gracia y Justicia para que se digne hacerlo presente á $\mathrm{Su}$ Magestad Católica $^{28}$.
\end{abstract}

Por su parte, el ministro de Gracia y Justicia se muestra propicio a autorizar al obispo auriense la cesión de la jurisdicción expresada para que se armonicen las divisiones eclesiásticas y civiles de ambos países ${ }^{29}$. En la misma dirección, se muestra el parecer de la Santa Sede sobre tan gravoso asunto ${ }^{30}$. De esta manera se lo hace saber el cardenal secretario de Estado al nuncio apostólico de $\mathrm{Su}$ Santidad en España tras conocer la súplica dirigida al Santo Padre por medio del embajador de Su Majestad Fidelísima junto a la Santa Sede, pidiendo que ambas parroquias sean incorporadas a la de Braga. El nuncio así se lo manifiesta

\footnotetext{
${ }^{26}$ Oficio del secretario de Estado de los Negocios Eclesiásticos y de Justicia de Portugal al obispo de Ourense. Braga, 3 de marzo de 1881, en ASV, Arch. Nunz. Madrid, caja 535, título VI, rúbrica I, sección I, núm. 19, fol. 692r-v.

${ }^{27}$ Oficio del obispo de Ourense al ministro de Gracia y Justicia de Su Majestad Consorte. Ourense, 15 de marzo de 1881, en ibíd., fol. 694r-v.

${ }^{28}$ Oficio del obispo de Ourense al secretario de Estado de los Negocios Eclesiásticos y de Justicia de Portugal. Ourense, 15 de marzo de 1881, en ibíd., fol. 693r-v.

${ }^{29}$ Oficio del ministro de Gracia y Justicia al obispo de Ourense. Madrid, 8 de noviembre de 1881, en ibíd., fol. 695r.

${ }^{30}$ Oficio del secretario de Estado al nuncio de Su Santidad en Madrid. Roma, 15 de septiembre de 1881, en ASV, Arch. Nunz. Madrid, caja 512, título VI, rúbrica I, sección I, núm. 35, fol. 419r-v. Se trata del Despacho núm. 46045.
} 
a monseñor Rodrigo, tras saber de la anuencia y conformidad del Gobierno español sobre este tema ${ }^{31}$.

Debiendo hacerse cuanto antes la nueva circunscripción de las diócesis portuguesas y recibiendo el placet del nuncio apostólico y del ministro de Gracia y Justicia, el prelado auriense no encuentra dificultad alguna en que se acceda a la petición del Gobierno de Portugal ${ }^{32}$.

\subsection{La bula de León XIII}

Por la bula Gravissimum Christi Ecclesiam regendi et gubernandi munus del papa León XIII, dada en Roma el 30 de septiembre de 1881, quedan incorporadas perpetuamente al arzobispado de Braga las parroquias referidas, enclavadas en territorio portugués y pertenecientes hasta ahora a la diócesis de Ourense. Dicha bula se ejecutó el 4 de septiembre de 1882, por parte del cardenal D. Américo, obispo de Oporto. La sentencia ejecutorial de la bula citada dice así, textualmente:

Gravissimum Christi Ecclesiam regendi et gubernandi munus = huius Regni Gubernio potestatem facit, ut in toto Lusitano Continenti Dioecesium reductionem novamque circumscriptionem inire valeat. Prolatae Litterae decernunt, praeter alia, ut, de Venerabilis Fratris Auriensis in Hispaniarum Regno Episcopi consensu sive rato sive praesumpto, duae parochiae = San Pedro de Tourém, scilicet, et Sancta Maria de Lama de Arcos = nuncupatae, eius spirituali jurisdictioni usque adhuc subjectae, ab eadem perpetuo disjungantur, Metropolitanaeque Ecclesiae Bracharense perpetuo pariter incorporentur, quando in Lusitano quidem territorio existant, et politicae Regis Fidelissimi potestati obnoxiae sunt ${ }^{33}$.

Una semana después responderá monseñor Rodrigo Rodríguez mostrando su docilidad a la ejecución de las letras apostólicas presentadas por el obispo de Oporto. Por su parte, el arzobispo de la primada portuguesa se muestra complacido ante tal acuerdo y expone su parecer en los siguientes términos:

\footnotetext{
${ }^{31}$ Carta oficial del nuncio apostólico al obispo de Ourense. Madrid, 20 de octubre de 1881, en ASV, Arch. Nunz. Madrid, caja 535, título VI, rúbrica I, sección I, núm. 19, fol. 695v.

${ }^{32}$ Contestación del obispo de Ourense al nuncio apostólico. Ourense, 25 de octubre de 1881, en ibíd., fol. 696r-v.

${ }^{33}$ Comunicación oficial del cardenal obispo de Oporto al obispo de Ourense haciéndole saber de la Bula de León XIII. Porto, 10 de febrero de 1882, en ibíd., fols. 687v-688r.
} 
Quer Sua Santidade que estas suas Letras Apostolicas em tempo algum, por qualquer motivo ou pretexto, nem mesmo o de nao terem sido ouvidos os interesados, possam ser contestadas, e sempre sejam cumpridas assim em juizo como fora d'elle, declarando irrito e nullo tudo quanto contra as mesmas for atentado. Eis eiqui Excmo. e Rvmo. Sr. como ó Sanctissimo Padre Leao XIII quer pola sua Auctorida Apostolica que figurem desligadas para sempre da jurisdicçao de V. E. R. as duas parochias situadas em territorio portugués, é figurem ligadas é incorporadas a esta Archidiocese de Braga $^{34}$.

Acabamos de asistir paso a paso al desarrollo del proceso por el que se pretende establecer cierta armonía entre los límites civiles y eclesiásticos de estos dos países vecinos. Copia de toda la documentación original generada en esta tramitación, quiso el obispo auriense, que se guardara en el archivo de su Secretaría de Cámara ${ }^{35}$.

\subsection{Los casos de Lapela y Azureira}

Por lo que se refiere a Galicia, no es el único caso encontrado en los fondos de Nunciatura, del Archivio Segreto Vaticano. De la primavera de 1887, es el pequeño haz de oficios y despachos que recogen la noticia del decreto de la Sagrada Congregación Consistorial que manda separar dos barrios situados en territorio portugués, aunque dependientes de la diócesis auriense, e incorporarlos a la jurisdicción eclesiástica de Tui.

Se trata de los barrios de Lapela y Azureira, inclusos en el término parroquial de Padrenda, feligresía orensana. El encargado de la ejecución de las letras apostólicas sería en un primer momento el arzobispo de Santiago. He aquí los términos con que el nuncio informa de este cometido al obispo tudense:

Es muy reciente el caso análogo de haberse separado dos parroquias de la diócesis de Orense para incorporarlas à la de Braga, en cuya ocasión no fue ejecutor de las relativas Letras el prelado de Braga, à pesar de ser Arzobispo. Por estas razones he venido en la determinación de subdelegar al Señor Arzobispo de Santiago, como digno Metropolitano de Usted la ejecución del referido

\footnotetext{
${ }^{34}$ Oficio del arzobispo de Braga al obispo de Ourense. Braga, 19 de noviembre de 1883, en ibíd., fols. $699 \mathrm{v}-700 \mathrm{r}$.

35 Oficio del obispo de Ourense al nuncio de Su Santidad en España. Ourense, 3 de marzo de 1887, en ibíd., fol. 690r.
} 
decreto Non raras relativo à la incorporación de los barrios de Lapela y Azureira à la diócesis de Tuy, pero antes de expedir el necesario decreto, he querido avisárselo à Usted estando, como estoy, dispuesto à elegir otra persona por si Usted tuviera motivo de preferirla à la del Señor Arzobispo de Santiago ${ }^{36}$.

Finalmente, el obispo metropolitano será excusado de esta tarea ante el obispo de Tui al argumentar la dificultad del viaje, ya que para su realización le sería necesario emplear toda una jornada. Por este motivo, considera que convendría delegar esta misión en la persona del prelado de As Burgas por reducirse su trayecto a dos horas en ferrocarrii ${ }^{37}$.

Monseñor Cesáreo Rodrigo, sintiéndose seguro por la experiencia adquirida recientemente con la incorporación de las parroquias de San Pedro de Tourém y Santa María de Lama de Arcos al arzobispado de Braga, parece disponible a asumir las facultades que le han sido otorgadas para llevar a efecto el decreto ya citado $^{38}$, tal como se lo comunica el nuncio de Su Santidad ${ }^{39}$.

\section{El arreglo de los lugares de Cambedo y Soutellinho}

El último arreglo del que tengo noticia acerca del continuado interés por delimitar las fronteras pública y eclesiástica entre los reinos de España y Portugal, se sitúa en el 7 de agosto de 1914, data del decreto de la Sagrada Congregación Consistorial, por el que se sustraen a la diócesis auriense los lugares de Cambedo y Soutellinho, que siendo civilmente dependientes del reino de Portugal, se agregan a la archidiócesis de Braga, tras haber sido llevado a ejecución tal decreto por parte del nuncio apostólico el 27 de noviembre del mismo año ${ }^{40}$.

Veamos pausadamente el desarrollo de este proceso, exponiendo antes a grandes rasgos el contenido que corresponde a los términos "Couto Mixto" y "Pueblos Promiscuos".

\footnotetext{
${ }^{36}$ Oficio del nuncio de Su Santidad al obispo de Tui. Madrid, 6 de marzo de 1887, en ibíd., fol. $683 \mathrm{r}-\mathrm{v}$.

${ }^{37}$ Oficio del obispo de Tui al nuncio de Su Santidad en España. Tui, 8 de marzo de 1887, en ibíd., fol. $685 \mathrm{r}-\mathrm{v}$.

${ }^{38}$ Oficio del obispo de Ourense al nuncio de Su Santidad. Ourense, 15 de marzo de 1887, en ibíd., fol. 673r.

${ }^{39}$ Oficio del nuncio de Su Santidad en España al obispo de Ourense. Madrid, 12 de marzo de 1887, en ibíd., fol. 687r-v.

${ }^{40}$ Boletín Oficial de la Diócesis de Orense, LXXXII, núm. 1869 (24 abril 1915), págs. 118-120.
} 


\subsection{El "couto mixto"}

Por el Tratado de Límites de 1864, firmado entre el Gobierno Español y el del entonces Reino de Portugal, se estableció la demarcación definitiva de ciertos límites fronterizos, ocupando buena parte de aquel tratado la argumentación referida a la frontera luso-orensana. Lo mismo ocurre con el canje de notas formalizado entre los dos países en 1906. Los acuerdos alcanzados fueron fruto de un laborioso ejercicio político y diplomático de ambos gobiernos.

Entre todas las zonas fronterizas hispano-portuguesas que presentaban singularidades en el momento del refrendo del mencionado Tratado de 1864, destacó de forma sobresaliente, el denominado "Couto Mixto", que si hubiera permanecido en el presente tendría un status semejante al del Principado de Andorra a la vez que una serie de privilegios —nacionalidad, cargas fiscales, exención de sangre, armas, impresos oficiales, autogobierno, derecho de asilo, ferias y mercados, camino privilegiado, cultivos, etc.— que aportarían a esta comarca la prosperidad que hoy no tiene.

Tal "Couto Mixto" está compuesto por tres poblaciones, a saber: Rubiás, Santiago y Meaus. Se trata de un territorio comprendido hoy dentro de los municipios orensanos de Calvos de Randín y Baltar. Su extinción se logró con el Tratado de Límites suscrito el 29 de septiembre de 1864, pasando tales poblaciones al Estado español, a cambio de ceder al Reino de Portugal los "pueblos promiscuos" de Souteliño, Cambedo y Lamadarcos, ubicados en los confines de Oimbra y Verín en relación con la nación lusa ${ }^{41}$.

Hacia el momento de anexión del "Couto Mixto" a la Corona española, Santiago contaba con unos cien vecinos, siendo el lugar más poblado; mientras que Meaus y Rubiás con setenta y ochenta, respectivamente, contabilizaban un número menor. En total, cerca de mil habitantes con doscientas cincuenta casas habitables. La principal actividad de estas poblaciones era la agropecuaria y comercial, contando en general con un bajo nivel cultural.

Si el origen del "Couto Mixto" está todavía oculto entre la nebulosa del pasado histórico, siendo la conjetura más fiable aquella que lo sitúa en el siglo XII con el nacimiento del Reino de Portugal, también lo está su evolución hasta el siglo XVI, época de la que apenas conocemos más que los desórdenes y tumultos provocados por las poblaciones de Barroso, en Portugal, y las de Randín, en España, teniendo que intervenir las autoridades portuguesas y españolas representadas, respectivamente, por el duque de Bragança y el conde de Monterrei ${ }^{42}$.

\footnotetext{
${ }^{41}$ Delfín Modesto Brandon, Historieta del Coto Mixto, La Coruña, Imprenta Tierra Gallega, 1907. El autor fue juez del "Couto Mixto".

42 José Baptista Barreiros, Delimitaçao da Fronteira Luso-Espanhola, Braga, O Distristo de Braga, 1961, págs. 29, 367 y siguientes.
} 
Lamentablemente para la conservación de la memoria histórica de este singular territorio, durante la retirada de las tropas francesas en la guerra de la Independencia, el general Soult, duque de Dalmacia, mandó quemar todo cuanto pudo, entre otras cosas de apreciable valía el archivo del "Couto Mixto"43.

\subsection{Los "pueblos promiscuos"}

Por lo que se refiere a los "Pueblos Promiscuos" que por el Tratado de Límites fueron incorporados a la soberanía portuguesa, estos se caracterizaban por la peculiaridad de estar situados materialmente sobre la raya fronteriza de ambos países, entre los municipios españoles de Oimbra y Verín, y el vecino ayuntamiento portugués de Chaves. Tal es el caso, que se consideraba normal que la divisoria fronteriza cruzara una población de tal modo que pertenecieran sus dos partes a diferentes países, e incluso que alguna casa tuviera en su interior tal línea divisoria, por la que contando la misma con dos puertas, una se abriera a España y otra a Portugal. Tales circunstancias provocaban situaciones de burla a las autoridades aduaneras y choques perjudiciales para la buena armonía que debería existir entre aquellas gentes ${ }^{44}$.

Se desconoce el origen de la situación anómala de estos pueblos, contando con un primer testimonio documental de 1526. Desde entonces hasta 1864, permanecieron en el tiempo los tres pueblos promiscuos a pesar de sus aparentes anomalías. Estas poblaciones no gozaban de privilegio alguno teniendo que contribuir fiscalmente a sus países respectivos. Tal vez la única ventaja viniera propiciada por su condición fronteriza por lo que se refiere al comercio y al mercado de contrabando, sobre todo teniendo en cuenta que muy pocas de sus hectáreas eran de calidad para el cultivo, como he podido comprobar personalmente al visitar estas aldeas dotadas más bien de una fisonomía agreste y montañosa. A mediados del siglo XIX, Souteliño contaba con ochenta vecinos que vivían en territorio portugués y doce en el español; Cambedo con trece vecinos portugueses y veinticinco españoles; y Lamadarcos con cincuenta y dos portugueses y veinticinco españoles.

El proceso de negociación de las dos delegaciones, hispana y lusa, en busca de una acertada conformación de los lindes geográficos de ambos países, encontró en la vía diplomática la mejor baza. De esta manera, el Tratado de Límites convenido en Lisboa determina en el artículo 10 que "el pueblo promiscuo de Soutellinho pertenecerá a Portugal demarcándose en territorio de España una zona de 90 a 100 metros de ancho contigua a la población”, y en el artículo 11 se

\footnotetext{
${ }^{43}$ Coto Mixto, en Gran Enciclopedia Gallega, 7 (1973), pág. 260.

${ }^{44}$ Luis Manuel García MAÑá, La frontera hispano-lusa..., págs. 110-115.
} 
acuerda que "los pueblos promiscuos de Cambedo y Lamadarcos con sus actuales términos pertenecerán a Portugal”. De esta manera, se consumaba la anexión de los tres pueblos promiscuos a Portugal ${ }^{45}$.

\subsection{Aplicación del tratado de límites}

Dato reseñable para nuestro estudio es aquel que se refiere a un acto de extrema parcialidad ejecutado en el atrio de la iglesia de Santiago, escenario donde se firma un documento el 21 de octubre de 1819 por el que se reconocían básicamente los privilegios inmemoriales citados más arriba de los lugares mixtos, pero ligando el "Couto Mixto" a la Casa de Bragança, lo que no mermaba para nada otras dependencias jurisdiccionales como lo era la eclesiástica por la que estas tres poblaciones, constituyendo entonces una única parroquia, recibían a su párroco tras la presentación de la Casa de Monterrei y su nombramiento por el prelado de la diócesis de Ourense.

Por tanto, cabe concluir que en lo religioso, el "Couto Mixto" perteneció siempre a la diócesis auriense, lo que no era de extrañar, ya que también perteneció a esta iglesia gallega, hasta 1882 la vecina feligresía portuguesa de San Pedro de Tourém. En la actualidad, la población de Meaus pertenece a la parroquia de San Lourenzo de Tosende y la de Santa María de Rubiás a la parroquia de Santiago de Rubiás dos Mixtos $^{46}$.

En este contexto, se entiende que hubiera tenido lugar la ya referida tentativa que se tradujo en realidad de desmembrar las dos parroquias orensanas de San Pedro de Tourém y Santa María de Lama de Arcos, pasando a formar parte de la archidiócesis bracarense. Así convergían los lindes civiles con aquellos eclesiásticos, evitándose para el futuro las dificultades que se encontrarían fácilmente en la administración de dichas feligresías, de no coincidir con la delimitación de las fronteras estatales entre España y Portugal.

Lo que pedía el secretario de Estado de los Negocios Eclesiásticos y de Justicia del vecino Reino de Portugal, es que estas dos parroquias fueran incorporadas a la diócesis primada de Braga y, por tanto, se agregaran ya definitivamente al territorio del Reino de Portugal, tal como así se hizo definitivamente. He aquí otro fragmento de la bula Gravissimum Christi Ecclesiam regendi et gubernandi munus del papa León XIII, dada en Roma el 30 de septiembre de 1881, sobre dicho cometido:

\footnotetext{
${ }^{45}$ Fronteras, en Diccionario Aranzadi de Legislación, que recoge el Convenio de Lisboa de 1864.

46 José Carlos Fernández Otero, Guía de la Diócesis de Ourense..., págs. 85 y 88.
} 
At vero cum Nostrum consilium Nostraque mens ea fuerit, ut nova haec in Lusitano Continente Dioecesium circumscriptio, omnes e medio tollens difficultatem causas, uberrimus pro rei catholicae incremento fructus producere valeat, laudati Ludovici Regis Fidelissimi votis omnino obsecundare cupientes, unam quoque et alteram paroecias San Pedro de Tourem et Santa Maria de Lama de Arcos, vernaculae respective noncupatas, in territorio Lusitano exstantes et politicae ipsius laudati Regis Fidelissimi potestati obnoxias sed spiritualiter quidem Ordinario finitissimae Cathedralis Ecclesiae Auriensis in Hispaniarum Regno sitae subiectas de Venerabilis etiam Fratris Nostris Auriensis Episcopi consensu sive rato sive presumpto, et quatenus opus sit consensum huiusmodi supremae Nostrae Auctoritatis plenitudine supplentes, ab eadem Auriensi Dioecesi et a quamvis praefati illius Ordinarii iurisdictione, dependentia et subiectione perpetuo dismembramus... easque cum omnibus et singulis utriusque sexus incolis... Metropolitanae Ecclesiae Bracharensi in eodem Continenti Lusitano perpetuo pariter unimus, attribuimus atque incorporamus ${ }^{47}$.

\subsection{Planteamiento de un problema}

Después de ilustrar los elementos principales del objeto de nuestro estudio, parece conveniente adentrarnos en el quid de la cuestión planteada a partir de un haz de cartas hallado en La Ciudad del Vaticano, en el archivo de la Segreteria di Stato, primer dicasterio pontificio desde el que recibe sus directrices el gobierno de la Iglesia Católica. Es digno de mención este caso por la peculiaridad del mismo, a la vez que resulta de interés para dar a conocer el modo de actuación sobre el particular.

El título del protocolo núm. 70104 es el siguiente: Dismembramento di alcune parrochie della diocesi di Orense per darsi alla Sede portoghese confinante con sistemazione secondo $i$ confini politici $i^{48}$. Como se puede advertir este titular no es del todo exacto, porque no se trata de parroquias, sino de poblaciones. Estas imprecisiones no nos han de extrañar en quienes son profanos a los términos arriba expuestos, repitiéndose tales inexactitudes en más de una ocasión a lo largo de la exposición de los referidos despachos.

\footnotetext{
${ }^{47}$ Comunicación oficial del cardenal obispo de Oporto al obispo de Ourense haciéndole saber de la Bula de León XIII. Porto, 10 de febrero de 1882, en ASV, Arch. Nunz. Madrid, caja 535, título VI, rúbrica I, sección I, núm. 19 , fols. $687 \mathrm{~V}-688 \mathrm{r}$.

${ }^{48}$ ASV, Segr. Stato, 1914, rúbrica 262, fol. 64r, núm. protocolo 70104.
} 
Abre el curso de esta correspondencia una carta oficial del conde de Viñaza, embajador de España ante la Santa Sede, que envía a su eminencia el cardenal secretario de Estado Rafael Merry del Val, con fecha del 16 de marzo de 1914. En la misma recuerda el Tratado de Límites de Lisboa de 1864, que tenía por objeto la demarcación de ciertos límites fronterizos entre los países de España y Portugal, procediéndose a la repartición del llamado "Couto Mixto" que se componía de seis pueblos — una inexactitud más—, tres de los cuales, Santa María de Rubiás, Santiago y Meaus pasaron a formar parte de la Monarquía española, mientras los otros tres, Souteliño, Cambedo y Lamadarcos fueron a quedar bajo la portuguesa.

Aparte de las imprecisiones, al estipularse aquel pacto no se reparó en que los pueblos mencionados se hallaban sometidos a la jurisdicción eclesiástica de diversas diócesis, y de esta manera se dio el caso anormal de que Cambedo y Souteliño, que eran de nacionalidad portuguesa desde hacía cincuenta años, continuaban formando parte del Obispado español de Ourense, circunstancia que si desde antiguo había dado lugar a pequeñas pero continuas dificultades entre ambos países, estas habían sido mucho mayores en los últimos tiempos con el cambio de régimen en Portugal, de la Monarquía a la República, y la consiguiente severidad de sus autoridades civiles con el libre ejercicio del culto católico sobre todo ante anomalías como la presente.

De ahí que hubieran surgido recientemente numerosos conflictos a consecuencia de la negativa de que sacerdotes españoles pasaran libremente, es decir, sin salvoconductos especiales, la frontera con objeto de ejercer su sagrado ministerio en los pueblos aludidos y otras vejaciones que por redundar en perjuicio del culto alarmaron justamente al obispo de Ourense, quien las había señalado repetidamente al Gobierno de $\mathrm{Su}$ Majestad. Estas medidas restrictivas tomadas en la frontera no eran de carácter particular y dirigidas contra determinados sacerdotes, sino generales y encaminadas a precaverse contra cualquier tipo de conspiración monárquica.

Sin embargo, tal estado de cosas no podía continuar subsistiendo sin que se vieran continuamente lesionados los intereses espirituales de Cambedo y Souteliño. Por otra parte, la permanencia de estos pueblos bajo la jurisdicción del Obispado de Ourense, que, como ya se ha dicho, habían dejado de pertenecer a la Monarquía española, no reportaba beneficio alguno apreciable ni a España ni a aquella diócesis. Por todo lo que aquí se ha dicho, se habría de solicitar de la Santa Sede que, una vez estudiado el asunto, se tuviera a bien segregar de la 
diócesis española de Ourense estos dos pueblos portugueses e incorporarlos a la diócesis lusitana que estimara más apta para el servicio del culto católico ${ }^{49}$.

En términos similares, se había manifestado el embajador extraordinario y plenipotenciario del Monarca español, el conde de Viñaza, ante el nuncio de $\mathrm{Su}$ Santidad en Lisboa. Su auditor, Benedetto Aloisi Masella, en un oficio al secretario de Estado, le sugeriría que procediera cuanto antes al arreglo de la demarcación geográfica de la diócesis auriense en relación con las diócesis portuguesas confinantes de Braga y Bragança, a fin de examinar a cual de las mismas deberían ser agregados estos dos pueblos ${ }^{50}$.

Una semana después, el nuncio de Lisboa dirigiría una nueva comunicación a Roma añadiendo toda la información posible sobre esta cuestión. Al respecto, enviaría el informe pedido al doctor Coria Pimoes, vicario capitular de Braga, así como el parecer de la Comisión de Ejecución de la Ley de Separación del 29 de agosto de 1913 y una copia de la bula pontificia de León XIII ${ }^{51}$. Estos dos últimos documentos llegarían de inmediato a las oficinas de la Curia Pontificia, mientras que el parecer del vicario capitular de Braga, que databa del 9 de mayo de 1914, sería enviado a Roma por el nuncio a fecha de 12 de mayo ${ }^{52}$.

\subsection{Parecer del nuncio Ragonesi}

Más extensa y rica en detalles es la exposición del nuncio de Su Santidad en Madrid, Francesco Ragonesi, dirigida meses después a su eminencia Rafael Merry del Val, en la que constata como el Tratado de 1864 no tiene en cuenta para nada a la autoridad eclesiástica, por lo que el obispo de Ourense, monseñor Ilundain y Esteban, continúa a ejercer su jurisdicción sobre las poblaciones asignadas a Portugal. Como consecuencia del Convenio de Lisboa, el gobierno de $\mathrm{Su}$ Majestad Fidelísima impetra de la Congregación Consistorial las providencias oportunas para reducir el número de diócesis portuguesas de diecisiete a doce, a la vez que pretende una nueva circunscripción de las mismas.

En tal ocasión el gobierno portugués retiene como oportuno el procurar la armonía de los confines eclesiásticos con aquellos políticos y, en consecuencia, obtiene de la diócesis auriense la desmembración de dos parroquias situadas en

\footnotetext{
${ }^{49}$ Oficio del embajador español ante la Santa Sede dirigido al secretario de Estado. Roma, 16 de marzo de 1914, en ibíd., fols. 65r-67r.

${ }^{50}$ Oficio del auditor del nuncio de Lisboa al secretario de Estado. Lisboa, 22 de marzo de 1914, en ibíd., fols. 69r-70v.

${ }^{51}$ Oficio del nuncio de Lisboa al secretario de Estado. Lisboa, 28 de marzo de 1914, en ibíd., fols. 86r-87r.

${ }^{52}$ Oficio del nuncio de Lisboa al secretario de Estado. Lisboa, 12 de mayo de 1914, en ibíd., fols. 91r-92r.
} 
territorio portugués, las de San Pedro de Tourém y Santa María de Lama de Arcos, que habían pasado a depender de la autoridad del Primado de Braga.

En la bula Gravissimum Christi Ecclesiam del Papa León XIII, ejecutada por el obispo de Porto, se recoge un elenco de las parroquias pertenecientes a las diócesis portuguesas fronterizas, designando como pertenecientes a la archidiócesis bracarense las parroquias de San Antonio de Souteliño y San Thiago de Villarelhos, las cuales abrazan, como parece, una parte de las poblaciones de Souteliño y Cambedo, que por defecto de una exacta designación, o bien por inadvertencia, o bien por otras razones, no pasaron a depender de la jurisdicción del arzobispo de Braga ${ }^{53}$.

Monseñor Ragonesi, nuncio de Madrid y arzobispo de Mira, en un esfuerzo continuo por ofrecer toda la información posible sobre el particular, envía otro comunicado a la Santa Sede en el que completa el contenido del despacho anterior número 71528, haciendo constar que en la Sagrada Congregación Consistorial hay una carta del 13 de diciembre de 1913, en la que el vicario capitular de la archidiócesis de Braga asevera la necesidad de que la aldea de Cambedo pase cuanto antes a la jurisdicción bracarense, teniendo en cuenta las presentes dificultades políticas surgidas en Portugal.

Obtenido el consentimiento del obispo de Ourense, quien precisa que en la mismas circunstancias de Cambedo se encuentra la aldea de Souteliño, se comunica al cardenal De Lai, prefecto del dicasterio consistorial, en una carta del 29 de enero de 1914, que para la recta administración espiritual de las dos citadas poblaciones convendría acoger la petición del vicario capitular de Braga y el oportuno beneplácito del Gobierno de Su Majestad el Rey, quien había aprobado la nueva circunscripción diocesana de 1893 en virtud del Real Patronato ${ }^{54}$.

Más tarde, con fecha del 9 de abril, el prelado auriense le comunicaba al nuncio una real orden del Presidente del Consejo de Ministros, del 18 de marzo de 1914, en la que se autorizaba al embajador de España ante la Santa Sede para que "solicite del Vaticano la segregación de los pueblos de Cambedo y Sontellinho de la Diócesis de Orense y su agregación a la portuguesa que estime más oportuno" "55. Días más tarde, a 21 de abril, se envía una copia de esta real ordenanza a la Congregación Consistorial, concluyendo el nuncio que lo mejor era incorporar las dos aldeas referidas a la archidiócesis de Braga, tal como era el sentir y la voluntad del prelado auriense y del Gobierno de España.

\footnotetext{
${ }^{53}$ Oficio del nuncio de Madrid al secretario de Estado. Madrid, 2 de junio de 1914, en ibíd., fols. 71r-74v, núm. protocolo 71528 .

54 "Arreglo parroquial de la Diócesis de Ourense", en Boletín Eclesiástico del Obispado de Orense, XLIII, núm. 1379 (7 diciembre 1893), págs. 1-98.

${ }_{55}$ Oficio del nuncio de Madrid al secretario de Estado. Madrid, 6 de junio de 1914, en ASV, Segr. Stato, 1914, rúbrica 262, fols. 83r-84r, núm. protocolo 71902.
} 


\subsection{Perspectiva portuguesa del problema}

Una de las lecturas más cualificadas sobre la cuestión ad hoc, es sin duda la que procede del vicario capitular de Braga, Antonio da Silva Coria Timoes, cuyo informe data del 9 de mayo de 1914. Según su testimonio, hasta 1864 había en los confines de esta archidiócesis diversas aldeas que pertenecían parte a España, parte a Portugal, tanto desde el punto de vista de una jurisdicción política como eclesiástica. En aquel año por un acuerdo entre los gobiernos de ambos países, con el cual algunas parroquias en zonas mixtas pasaron a Portugal y otras a España, Cambedo y Souteliño permanecieron dentro del territorio luso.

Tal separación se hizo sin tener presencia alguna la autoridad eclesiástica, con lo que las jurisdicciones de las diócesis auriense y bracarense se mantuvieron igual. Para resolver esta anomalía, en 1882 hubo una nueva distribución geográfica del mapa de la Iglesia portuguesa por la que se suprimieron algunas diócesis y además dos parroquias de Ourense pasaron a Portugal. En definitiva, la nueva circunscripción eclesiástica lusa se hacía conforme al sentir de la bula referida de León XIII, ejecutada por el cardenal de Porto. Por otra parte, se mantenía la jurisdicción del prelado auriense en Rubiás, Santiago y Meaus, pueblos que componían el "Couto Mixto", y en dos de los denominados pueblos promiscuos, que constituían el quid de la cuestión.

Es interesante hacer notar cómo el vicario capitular de Braga recoge el momento en que dudando el obispo de Ourense sobre su jurisdicción en parte de Souteliño, pide el parecer del arzobispo de Braga, monseñor Antonio Freitas Honorato, quien le responde tal como testimonia el nuncio de Madrid: "che dopo l'ultima circoscrizione ecclesiastica appartenevano all'archiciocesi di Braga tutte le famiglie della detta parrocchia esistenti in Souteliño" ${ }^{56}$. En fuerza de aquella respuesta, los párrocos de Souteliño habían ejercitado su jurisdicción eclesiástica sobre toda la población de tal nombre, sin guardarse de los derechos pretendidos o reales del prelado auriense.

En cambio, por lo que se refiere a la aldea de Cambedo, situada entre las dos parroquias de Villarelho da Raia — archidiócesis de Braga - y de San Cipriano de Oimbra, anejo de Santa María de Oimbra — diócesis de Ourense—, se verifica el hecho de que una veintena de familias lusas han permanecido sujetas hasta ahora a la jurisdicción del obispo de Ourense, quien la ejercita por medio del párroco de la feligresía de Oimbra.

Esta feligresía del valle de Verín pertenece a la dignidad de Varoncelle siendo cabeza de municipio. Se trata de un curato laical, con la categoría eclesiástica

\footnotetext{
56 Oficio del nuncio de Madrid al secretario de Estado. Madrid, 2 de junio de 1914, en ibíd., fols. 71r-74v, (núm. protocolo 71528.
} 
"de término", que en 1844 lo componían ochocientos cincuenta y cinco habitantes que se distribuían de la siguiente manera: Oimbra — sesenta vecinos-, Rosal — treinta—, Cambedo — veinte—, Tamaguelos — cuarenta—, San Cipriano - treinta y dos - y Rabal — treinta - . De los lugares mencionados, aparecían como anejos propios: Santa María de Tamaguelos, San Andrés de Rabal y Santa Cruz de San Cipriano ${ }^{57}$.

El que había sido párroco hasta hace poco, don Camilo Gómez Prieto, con sus ochenta y cinco años de edad, me decía cómo en los primeros años en que estuvo encargado de esta parroquia, numerosos feligreses de Cambedo acudían junto a él en busca de todo tipo de certificaciones, poseyendo el anejo de Santa Cruz de San Cipriano sus propios libros parroquiales a parte de aquellos de la matriz.

Pues bien, con el cambio de régimen político en Portugal, las autoridades lusas negaron su autorización a los sacerdotes orensanos para que pasaran libremente la frontera, a fin de ejercitar la cura pastoral entre los fieles de Cambedo, e incluso obstaculizaron que estos pudieran acceder al propio templo parroquial, obligándoles a enterrar sus muertos en el cementerio de Villarelho da Raia. Al respecto, lo expresa en estos términos el vicario capitular de Braga:

En Oimbra son baptisados as crianças nacidas em Cambedo e ahí se sepultam tambem as cadáveres das persoas fallecidas no mesmo lugar. Atí á proclamaçao da Republica em Portugal nao hanno consequencias de gravidade deste estado de cousas, mais despois de 1910 a situaçon dos fieis de Cambedo, na parte sujeita à jurisdicçao espiritual do Bispo de Orense, tornase verdadeiramente critica. Na verdade, por muitos meses, exigindose um salvoconducto para passar a fronteira, nem o parocho espanhol podia vir administrar os ultimos sacramentos aos seus subditos portugueses, nem estes podiam facilmente ir á sua igreja parroquial. Por orden das auctoridades da Republica as persoas fallecidas em Cambedo (parte espanhola) tiveram de ser sepultados no cemiterio da freguesia de Villarellos da Raia, á qual pertenece a outra parte da povoaçao de Cambedo. De todos estos factos o Bispo de Orense, a quando de sua visita pastoral á freguesia de Oimbra, instaura un processo a fim de diplomaticamente tratar esta questao. Effetivamente o consul espanhol no Porto tomou informaçoes junto do fallecido D. Manuel Baptista da Cunha, Arcebispo de Braga, o

\footnotetext{
${ }^{57}$ Relación núms. 1 y 2 de la parroquia de Santa María de Oimbra, en AHDOu, Estadística, libro 1844, leg. 6516.
} 
qual ja em jullo de 1909 tinha sido incomodado polo facto de ter constado un Ministerio dos Negocios Eclesiásticos que as crianças de Cambedo eram baptizados en Oimbra ${ }^{58}$.

A causa de la obligación de tener los entierros en Vilarelhos se tramitó una queja diplomática al Ministerio de Extranjería y por este al de Justicia y al gobernador civil de Vilarelhos, así como al administrador del ayuntamiento de Chaves para que compareciera el párroco de este lugar. Se acudió al arzobispado de Braga y, no hallando solución alguna, se creyó oportuno pasar el tema a Roma. Por tanto, Cambedo y Souteliño fueron los dos únicos lugares en que ejerció su jurisdicción el obispo de Ourense, no teniendo sentido esta excepción después de los arreglos anteriores.

Si no habían sido pocas las desavenencias, se sumó aquella por la que la Comisión Central Ejecutiva del decreto de la ley de Separación en Portugal, había emitido con fecha del 28 de agosto de 1913, un parecer según el cual no se podía tolerar desde la República la jurisdicción de un obispo extranjero - aquel de Ourense- en el territorio portugués de Cambedo. Todo esto explica los motivos para hacer coincidir los lindes eclesiásticos de las diócesis con aquellos políticos, así como la preocupación manifiesta del prelado auriense que dirigiéndose a la Corona española, había atraído la atención sobre el particular a fin de encontrar una pronta y pacífica solución. Al respecto, se expresaba así la referida Comisión:

A Republica nao pode conhecer da pretensa jurisdiçao espiritual do Bispo de Orense (Hispanha) na povoaçao de Cambedo, freguesia de Vilarelho da Raia, do concelho de Chaves ou em qualquer outra parte do terreno nacional porisso que a nao se manifestar essa jurisdicçao por actos externos contrarios ás leis portuguesas, o Governo deberá limitarse a manter impassivelmente, a liberdade religiosa nos termos em que a definem os $n .4$ a 10 e 12 do art. $3^{\circ}$ da Constituiçao. E a mesma doutrina terà de aplicarse á intervençao espiritual no territorio portugues de outro Prelado ou chefe estrangeiro de quelquer religiao. No convenio ou tratado de limites de 29 de setembro de 1864 polo qual passan inteiramente para a posse e soberania de Portugal a povoaçao promiscua de Cambedo e sem termo, nao se resalvou a favor do Bispo d'Orense a jurisdiçao espiritual sobre a respectiva populaçao; apenas se

\footnotetext{
${ }_{58}$ Informe del vicario capitular de Braga al nuncio de Madrid. Braga, 9 de mayo de 1914, en ASV, Segr. Stato, 1914, rúbrica 262, fols. 93r-95v.
} 
garantin a nacionalidade dos subditos hespanhoes que ali residissem (art. 11 e 27). Por tanto só é legitima a presunçao de que a jurisdiçao ecclesiastica seguiu a soberania nacional (!), devendo desde entón considerarse abusiva a intervençao dos Bispos e do parocho de Oimbra na paroquialidade da paroaça de Cambedo ${ }^{59}$.

A esta declaración sigue la recopilación de algunos párrafos del decreto ejecutado en Portugal para una nueva circunscripción de la Iglesia portuguesa, llevada a término por el Papa León XIII y el cardenal de Porto. Asimismo se halla reflejado a continuación el elenco de las parroquias pertenecientes a las diversas diócesis lusas entre las que se encontraban las destinadas a la archidiócesis primada como pertenecientes al ayuntamiento de Chaves, que eran las que siguen: Nuestra Señora de la Concepción de Lama de Arcos, Santa María de Lama de Arcos, San Antonio de Souteliño y San Thiago de Villarelhos ${ }^{60}$. En conformidad con este elenco, parece que la aldea de Cambedo ha de pertenecer a la parroquia de Villarelhos.

Tanto el patriarca de Lisboa, interrogado por monseñor Benedetto Aloisi Masella, auditor de aquella Nunciatura Apostólica, como el vicario capitular de Braga, opinan que el objeto de la última circunscripción eclesiástica en Portugal fue también aquel de hacer coincidir los confines eclesiásticos con los políticos, y que las citadas aldeas de Souteliño y Cambedo pertenecieran ya de derecho a la archidiócesis bracarense.

También se apunta que si tales aldeas no fueron mencionadas explícitamente en la bula de circunscripción o en el relativo decreto de ejecución, esto debería atribuirse a descuido del cardenal-obispo de Porto, Américo dos Santos Silva — explicable si se considera la poca importancia de las mismas aldeas-, o bien a no haberse considerado como necesaria tal mención, ya que se trataba de poblaciones insignificantes, y era evidente el objeto de la bula con la que se incorporaban a Braga las parroquias de Tourém y Lama de Arcos, las cuales abrazaban la mayor parte de la población que con el Tratado de 1864 se había pasado a Portugal.

\footnotetext{
${ }_{59}$ Parecer da Commissao Central da execuçao da lei de separaçoes de 28 de Agosto de 1913, en ibíd., fols. 88r-90r.

${ }^{60}$ Paula Godinho, "Três olhares da antropologia sobre a fronteira galaico-portuguesa", Lethes. Cadernos culturais do Limia, 6 (2005), págs. 78-113.
} 


\subsection{Al fin, una solución}

Una vez puestos sobre el tapete los diferentes dictámenes de los gobiernos políticos de España y Portugal, así como los pareceres e informes de los nuncios de Madrid y Lisboa, la Santa Sede por medio de la Sagrada Congregación Consistorial asume la responsabilidad de cotejar todos aquellos elementos para lograr una solución satisfactoria. El cardenal Gaetano de Lai, prefecto de este dicasterio, envía al cardenal Merry del Val, secretario de Estado, un oficio con número de protocolo 71727, y fecha del 13 de junio de 1914, en el que expone la providencia pontificia acordada sobre este particular.

En su primera parte, expone las circunstancias concretas ya aludidas del Tratado de 1864 con las decisiones tomadas sobre el "Couto Mixto" y los "Pueblos Promiscuos", la no presencia e intervención de la autoridad eclesiástica en tales diatribas con lo que el prelado auriense sigue ejerciendo su jurisdicción sobre poblaciones asignadas a Portugal, y las providencias impetradas por la monarquía lusa ante la Santa Sede para la reducción de las diócesis portuguesas y una nueva circunscripción de las mismas.

También recuerda la iniciativa por la que se procura la armonía de los confines eclesiásticos con aquellos políticos al obtener el desmembramiento de las parroquias de Tourém y Lama de Arcos de la diócesis de Ourense, y su incorporación a la archidiócesis de Braga por la bula Gravissimum Christi Ecclesiam. Al mismo tiempo, recoge la conjetura por la que las poblaciones de Souteliño y Cambedo habrían de ser consideradas bajo la autoridad de la archidiócesis primada de Portugal, a pesar del silencio jurídico que sobre las mismas existe en cuanto que siguen dependiendo del obispo de Ourense.

Se relatan las circunstancias actuales por las que veinte familias portuguesas de la aldea de Cambedo son atendidas espiritualmente por el párroco orensano de Oimbra, constituyéndose tal hecho en una provocación continua ante la nueva sensibilidad creada por el emergente gobierno republicano del país vecino. Tal disidencia entre jurisdicciones aumenta con la decisión asumida por la Comisión Central del decreto de la ley de Separación de no tolerar por más tiempo la intromisión de la autoridad de un obispo extranjero en el territorio portugués de Cambedo, por lo que los lindes eclesiásticos de las diócesis habían de coincidir con los políticos ${ }^{61}$.

Monseñor Ilundain y Esteban preocupado por el estado de las cosas, tiene la suficiente premura y acierto de indicarlo al Gobierno de Su Majestad Católica, quien por medio de su Embajador ante la Santa Sede pide que las citadas aldeas

\footnotetext{
${ }^{61}$ Oficio de la Congregación Consistorial al Secretario de Estado. Roma, 13 de junio de 1914, en ASV, Segr. Stato, 1914, rúbrica 262, fols. 75r-82v.
} 
de Cambedo y Souteliño sean desmembradas de la diócesis española para ser incorporadas a la correspondiente diócesis portuguesa. En similares términos se redacta la respuesta del Patriarca de Lisboa tras ser consultado por el auditor de aquella nunciatura, coincidiendo también en estos mismos planteamientos el vicario capitular de Braga, que dice:

Parmi fuori di dubbio che tanto Soutellinho quanto Cambedo dal 1882 appartengano realmente all'Archidiocesi di Braga. Effettivamente il fine della nuova delimitazione di diocesi fu quello di far coincidere la circoscrizione ecclesiastica con quella civile, fine che non si sarebbe conseguito qualora Cambedo non fosse rimasto appartenente all'archidiocesi di Braga. Ed invero perchè si dovrebbe ammettere un'eccezione per poche famiglie di due popolazioni insignificanti, quando è certo che parrocchie ben maggiori passarono sia alla Spagna come al Portogallo? [...] Benchè io non abbia alla mano una carta geografica del Portogallo colla divisione delle diocesi, non ho alcun dubbio che nella frontiera spagnuola la linea divisoria ecclesiastica si identifica con quella civile ${ }^{62}$.

Pero, ¿cómo explicar entonces una omisión de estas características por lo que se refiere a estas dos poblaciones en el decreto de ejecución de la bula de León XIII? No siendo fácil dar una respuesta positiva y categórica a tal pregunta, debemos recurrir a las hipótesis de trabajo que solo resultan ser probables. La primera explicación pudiera ser la de un simple olvido del cardenal Don Américo, inadvertencia no difícil de admitir por cualquiera si se considera el escaso número de familias pertenecientes a poblaciones tan poco importantes.

Otra explicación y en parte preferible, sería aquella que no consideraba necesaria la mención de las dos poblaciones. De hecho, en el decreto que aplica la bula pontificia apenas se recuerdan los nombres de las parroquias sin bajar a la designación de los lugares que les pertenecen a cada una. Así, las pocas familias de Cambedo no constituían una parroquia, puesto que algunas formaban parte de aquella de Oimbra y otras de aquella de Villarelho. Por tanto, no era necesario mencionar una porción de Cambedo, una vez que se declaraba como perteneciente a la archidiócesis de Braga todo el territorio portugués. El mismo razonamiento vale también para Souteliño.

Ahora bien, no se puede decir lo mismo para las dos referidas parroquias de San Pedro de Tourém y Santa María de Lama de Arcos, puesto que estas dos poblaciones son las sedes de dos parroquias y tienen por ello suficiente categoría

\footnotetext{
${ }^{62}$ Ibíd., fols. $79 \mathrm{v}-80 \mathrm{r}$.
} 
de carácter jurídico para ser expresamente mencionadas. Por tanto, el objetivo de establecer una nueva circunscripción eclesiástica y las palabras genéricas del decreto de aplicación de la bula leonina parecen excluir todo tipo de duda al respecto. En consecuencia, por lo expuesto hasta ahora, se ve claramente la conveniencia e incluso la necesidad de que sean incorporadas a la archidiócesis primada, si de derecho no lo habían establecido todavía, las referidas poblaciones de Cambedo y Souteliño.

El cardenal secretario de Estado, don Rafael Merry del Val, refiere cuanto precede al Santo Padre, el papa Pío X, quien habiendo reconocido, por los argumentos expuestos, la necesidad de que los confines eclesiásticos entre las diócesis de Ourense y Braga coincidan con aquellos políticos, y tras el parecer favorable del prelado auriense y el nuncio apostólico de Madrid, ordena que las tantas veces mencionadas poblaciones de Souteliño y Cambedo permanezcan incorporadas efectivamente, y de modo fehaciente, a la archidiócesis primada de Portugal.

Tal voluntad pontificia la transmite el cardenal secretario de Estado al prefecto de la Sagrada Congregación Consistorial, el cardenal Gaetano de Lai, para que establezca las órdenes que considere oportunas a fin de que tal decisión del papa Pío X venga a ser ejecutada cuanto antes. Así se hace saber a los gobiernos de ambos países por diversos oficios expedidos al mismo tiempo a fecha 19 de junio, y dirigidos uno al auditor de la nunciatura de Lisboa ${ }^{63}$ y otro al embajador de España ante la Santa Sede ${ }^{64}$.

El decreto de la Sagrada Congregación Consistorial data del 7 de agosto, correspondiendo su aplicación al nuncio apostólico de Madrid, monseñor Ragonesi, el 27 de noviembre de 1914. Dice así el texto original:

Ad incommoda praecavenda, quae facile oviri possunt ex eo quod pagi vulgo Cambedo et Soutellinho, dum civiliter ad Lusitaniam pertinent, subiiciuntur tamen ecclesiasticae iurisdictioni Episcopi Auriensis in Hispania; Sanctissimus Dominus noster Pius P. P. X, omnibus rite perpensis et servatis de iure servandis, duos memoratos vicos e dioecesi hispanica Auriensi dividere ac separare atque finitimae Lusitanae archidioecesi Bracharensi unire et aggregare statuit. [...] Ad haec autem exsequenda Beatissimus Pater deputare dignatus est R. P. D. Franciscum Ragonesi, Archiepiscopum ti-

\footnotetext{
${ }_{63}$ Oficio de la S. C. Consistorial al auditor de la nunciatura de Lisboa. Roma, 19 de junio de 1914, en ibíd., fol. 97r-v.

${ }^{64}$ Oficio de la S. C. Consistorial al embajador de España ante la Santa Sede. Roma, 19 de junio de 1914, en ibíd., fol. 98r-v.
} 
tularem Myrensem atque in Hispania Apostolicum Nuntium, eique tribuens necessarias et opportunas facultates etiam subdelegandi ad effectum de quo agitur quemlibet ecclesiastica dignitate ornatum, onere tamen ei imposito ad hanc S. Congregationem Consitorialem quamprimum transmittendi exemplar authenticum exsecutionis peractae. Datum Romae, ex Secretaria eiusdem Sacrae Congregationis die 7 mensis augusti anno 1914. = Card. De Lai ${ }^{65}$.

Recibida la comunicación del nuncio apostólico de Su Santidad en España y el decreto de la Sagrada Congregación Consistorial Ad incommoda praecavenda, monseñor Ilundain responde con un despacho en el que expone su compromiso de aplicar la documentación vaticana remitida. A 6 de diciembre del mismo año pone en conocimiento de los señores curas de Oimbra y Videferri, a cuyas parroquias pertenecían las aldeas de Cambedo y Souteliño, el contenido del mencionado decreto. Lo mismo hace en relación con el arzobispo primado de Braga y el nuncio de Madrid.

El canónigo y secretario de Cámara, don Jesús Gozalo, deja constancia de esta documentación en el archivo de la curia diocesana, así como en el Provisorato al estar en curso el expediente de la provisión del curato de Santa María de Oimbra. En el libro corriente de matrimonios de esta parroquia —en la comunicación al cura de Oimbra se añade "y en el de la filial de Santa Cruz de S. Ciprián" - y en el de visitas de Santa María de Videferri aparece transcrita literalmente tal providencia en los siguientes términos:

Hemos recibido el decreto de la $S$. C. Consistorial Ad incommoda praecavenda del 7 de Agosto del presente año, en el cual los pueblos de Cambedo y Soutellinho son segregados de la diócesis de Orense á la que pertenecían y agregados á la archidiócesis de Braga, de suerte que en adelante los límites eclesiásticos coincidan con los límites de España y Portugal ${ }^{66}$.

\section{Nuevos LÍMites DiOCESANOS EN EL SIGLO XX}

Habiendo determinado en el Concordato de 27 de agosto de 1953, la Santa Sede y el Gobierno español, entre otras cosas, que los actuales límites de las

\footnotetext{
${ }^{65}$ Decreto de la S. C. Consistorial. Roma, 7 de agosto de 1914, en AHDOu, Planteamiento del Arreglo Parroquial. Colecciones y posesiones de curatos. Año de 1894, libro $5^{\circ}$ [sin catalogar].

${ }^{66}$ El Archivo de la Curia Diocesana de Ourense está en proceso de catalogación.
} 
diócesis no comprendan distintas provincias civiles y que paulatinamente sean modificados de común acuerdo, el arzobispo titular de Sinada en Frigia y nuncio apostólico de Su Santidad en España, Hildebrando Antoniutti, después de haber convenido el asunto con el gobierno franquista, solicitó de la misma Sede Apostólica que la susodicha rectificación de confines eclesiásticos, ya establecida, en principio, fuera llevada a efecto en las provincias civiles de las regiones de Galicia, Asturias, León y Castilla.

En cuanto a la diócesis auriense, el decreto de la Sagrada Congregación Consistorial, firmado por el secretario Piazza, el obispo de Sabina y Poggio Mirteto, expone que las modificaciones que se han de realizar son las siguientes:

De la Diócesis de Astorga se separan para la de Orense tres parroquias en el enclave llamado de Castro Caldelas. De la Archidiócesis de Compostela se separa para la de Orense el territorio de Beariz con tres parroquias... De la Diócesis de Tuy se separa para la de Orense el arciprestazgo de Ribadavia, junto con doce parroquias, y los enclaves de Padrenda y Desteriz. De la diócesis de Orense se separan para la de Lugo los territorios de Búbal, con sus cinco parroquias y Torbeo con la parroquia de Nogueira, situados en la provincia civil de Lugo, y además doce parroquias situadas en la provincia civil de Zamora llamadas: Aciberos, Castrelos, Castromil ${ }^{67}$, Chanos, Edradas, Edroso, San Cibrao de Hermisende, Santa María de Hermisende, Lubián, Padornelo, Tejera y Villanueva de la Sierra. De la diócesis de Lugo se separa para la de Orense la parroquia de San Pedro de Espiñeira, situada en la provincia civil de Orense... Cambiados de esta manera los límites de las antedichas Diócesis, Su Santidad agrega: A la Diócesis de Astorga las doce antedichas parroquias separadas de la Diócesis de Orense... A la Diócesis de Orense las tres parroquias situadas en el territorio de Castro Caldelas y la parroquia llamada San Pedro de Gudiña, todas separadas de la Diócesis de Astorga; el Arciprestazgo de Ribadavia, junto con sus doce parroquias, además de las parroquias de Desteriz y Padrenda, separadas de la Diócesis de Tuy; las parroquias de Beariz, Girazga y Lebozán, restadas a la

\footnotetext{
${ }^{67}$ En la actualidad Castromil de Castilla y Castromil de Galicia forman una única parroquia perteneciente a la diócesis de Ourense. La sede parroquial se sitúa en el templo perteneciente a la parte castellana. Es el único núcleo no gallego que pertenece a la diócesis auriense.
} 
Archidiócesis de Compostela, y, por último, la citada de San Pedro de Espiñeira ${ }^{68}$.

El decreto que tiene fecha de 17 de octubre de 1954, fue ejecutado por la Nunciatura Apostólica de Madrid, el día 7 de marzo de $1955^{69}$. De esta manera, la diócesis auriense quedaba totalmente enclavada dentro de los límites de la provincia civil de este nombre, a no ser por la parte que corresponde a la de Astorga: O Barco, A Rúa, Viana do Bolo... La ratificación del mencionado decreto, que ponía fin a una disputa larga, sobre todo, entre las diócesis de Tui y Ourense, en cuanto a la división por el río Avia entre la villa de Ribadavia y el barrio que circunda al convento mendicante dedicado a San Francisco, aparece publicada en el boletín de la Santa Sede ${ }^{70}$.

El obispo Temiño notificó a la diócesis el contenido del decreto el 1 de agosto de 1955. Informa de la ejecución de dicho decreto, con fecha de 14 de marzo de 1955, apareciendo la relación de las parroquias que dejan de pertenecer a la diócesis de Ourense, de las parroquias que se integran a la diócesis auriense, así como de los sacerdotes que dejan de pertenecer a la diócesis de As Burgas y los que pasan a depender de la misma procedentes de Santiago, Astorga y Tui ${ }^{71}$.

En definitiva, el devenir manifestado en la delimitación de la geografía eclesiástica de la diócesis auriense resulta ser de cierta importancia, pudiendo contemplarse como los marcos espaciales de la misma siempre aparecen susceptibles al cambio motivado por las circunstancias de su tiempo. Espero haber puesto un poco de luz sobre este particular, siendo de especial relieve el buen hacer en concordia y entendimiento que ayuda a configurar los lindes diocesanos, incluso en su dimensión más internacional.

\footnotetext{
${ }^{68}$ Decreto sobre cambio de límites de la Diócesis de Burgos, Compostela, Oviedo, Valladolid y otras. Roma, 17 de octubre de 1954, en ASV, Congr. Consist., núm. 1456/54. Cfr. BOOO CXXII, núm. extraordinario (agosto de 1955), págs. 3-8, edición latina; págs. 8-13, edición castellana.

${ }^{69}$ Decreto de ejecución. Madrid, 7 de marzo de 1956, en ASV, Arch. Nunz. Madrid, núm. 516/55. Cfr. BOOO CXXII, núm. extraordinario (agosto de 1955), pág. 14.

${ }^{70}$ Acta Apostolicae Sedis, fasc. 9, (24 julio 1955).

${ }^{71}$ Boletín Oficial del Obispado de Orense, CXXII, núm. extraordinario (agosto de 1955), págs. 15 20.
} 
APUNTES SOBRE LA GEOGRAFÍA ECLESIÁSTICA DE OURENSE: TOURÉM,

\section{BIBLIOGRAFÍA}

Barreiros, José Baptista, Delimitaçao da Fronteira Luso-Espanhola, Braga: O Distristo de Braga, 1961.

Brandon, Delfín Modesto, Historieta del Coto Mixto, La Coruña, Imprenta Tierra Gallega, 1907.

Cárcel Ortí, Vicente, "Los despachos de la Nunciatura de Madrid (1847-1857)", Archivum Historiae Pontificiae, 13 (1975), págs. 311-400; 14 (1976), págs. 265-356.

Cárcel Ortí, Vicente, "El liberalismo en el poder (1833-68)", en Ricardo García Villoslada (coord.), Historia de la Iglesia en España: La Iglesia en la España contemporánea, vol. 5, Madrid, BAC, 1979, págs. 154-158.

Duro Peña, Emilio, "Las antiguas dignidades de la Catedral de Orense", Anuario de Estudios Medievales, 1 (1964), págs. 289-332.

Echeverría, Lamberto de, "El Concordato español de 1851", en Augustin Fliche - Victor Martín (coords.), Historia de la Iglesia, vol. 24, Valencia, EDICEP, 1976, págs. 594-611.

Fernández Otero, José Carlos, Guía de la Diócesis de Ourense, Ourense, Diputación de Ourense, 1997, págs. 31-76.

García Mañá, Luis Manuel, La frontera hispano-lusa en la provincia de Ourense, Ourense, Museo Arqueológico Provincial, 1988, 216 págs. (Anexo 11 de Boletín Auriense).

Godinho, Paula, "Três olhares da antropologia sobre a fronteira galaico-portuguesa", Lethes. Cadernos culturais do Limia, 6 (2005), págs. 78-113.

González García, Miguel Ángel, "La diócesis de Orense desde 1850”, en José García Oro (coord.), Historia de las diócesis españolas: Iglesias de Lugo, Mondoñedo-Ferrol y Orense, vol. 15, Madrid, BAC, 2002, págs. 536-538.

Hernández Figueiredo, José Ramón, “Tentativa por conformar las divisiones, eclesiástica y pública, de los Reinos de España y Portugal. El caso de las parroquias de San Pedro de Tourém y Santa María de Lama de Arcos”, Memoria Ecclesiae, 27 (2005), págs. 449-462.

Hernández Figueiredo, José Ramón, "El obispo Pedro de Quevedo y Quintano (1776-1818), víctima de la política liberal de las Cortes de Cádiz", Salmanticensis, 58, fasc. 2 (mayoagosto 2011), págs. 315-348.

Hernández Figueiredo, José Ramón, "Correspondencia vaticana inédita sobre la jurisdicción del deán Juan Manuel Bedoya, en sede vacante (1841-1847)", Auriensia, 15 (2012), págs. 207-304.

Hernández Figueiredo, José Ramón, El cardenal Pedro de Quevedo y Quintano en las Cortes de Cádiz, Madrid, BAC, 2012, XLVII+217 págs.

Hernández Figueiredo, José Ramón, “Manifiesto del canónigo cardenal Juan Manuel Bedoya en defensa de la pureza doctrinal que contienen sus escritos", Auriensia, 16 (2013), págs. 147-195.

Hernández Figueiredo, José Ramón, Actas inéditas del deán Juan Manuel Bedoya, durante su elección como gobernador eclesiástico de Ourense en sede vacante (1841-1847), Roma, Instituto Español de Historia Eclesiástica, 2013, 227 págs.

Ilundain y Esteban, Eustaquio, Constituciones Sinodales promulgadas por el Excmo. e Ilmo. Señor Dr. D. Eustaquio Ilundain y Esteban, obispo de Orense, senador del Reino, etc. etc. 
En el Sínodo Diocesano celebrado en la Santa Iglesia Catedral de Orense los días 14, 15 y 16 de junio de 1908, Orense, Imprenta de A. Otero, 1908, págs. 121-125.

Lemos Montanet, J. Leonardo, Carta pastoral Los arciprestazgos: una estructura viva para una tarea de futuro, Ourense, 2013.

Mansilla Reoyo, Demetrio, Geografía eclesiástica de España. Estudio histórico-geográfico de las diócesis, 2 vols., Roma, Iglesia Nacional Española, 1994.

Mercati, Angelo (ed.), Raccolta dei Concordati su materie ecclesiastiche tra la Santa Sede e le autorità civili, vol. 1: 1098-1914, Città del Vaticano, Tipografia Poliglotta Vaticana, 1954, págs. 771-795.

Pérez Alhama, Juan, La Iglesia y el Estado español. Estudio histórico-jurídico a través del concordato de 1851, Madrid, Instituto de Estudios Políticos, 1967.

Suárez, Federico, “Génesis del Concordato de 1851”, Ius Canonicum, 3 (1963), págs. 65-249. 